\title{
FREEDOM FROM NUCLEAR WEAPONS? IHRL AND IHL PERSPECTIVE VS THE STATE-CENTRED APPROACH ${ }^{1}$
}

\author{
JULIA KAPELAŃSKA-PRĘGOWSKA
}

\begin{abstract}
ICJ's Advisory Opinion on the Legality of the Threat or Use of Nuclear Weapons, a general treaty prohibiting the use of nuclear weapons has been adopted. It may be anticipated that the TPNW will probably not enter into force very soon, and when it does, it will neither be universally accepted, nor will it significantly influence the practice of the nuclear weapon States. It is therefore justified to analyse the problem under consideration, not from a State-oriented perspective, but from a human and environmentally centred one. The article argues not only that any use of nuclear weapons would be contrary to the rules of international law applicable in armed conflict, in particular the principles and rules of international humanitarian law, but it would also violate international human rights law. The article further dwells upon the customary international law aspects of the problem under consideration.
\end{abstract}

Keywords: Treaty on the Prohibition of Nuclear Weapons, persistent objector, protection of the environment, right to life, prohibition of nuclear weapons, human rights, international humanitarian law

Summary: 1. INTRODUCTION. 2. NuCLEAR WEAPONS IN INTERNATIONAL LAW - FROM DISARMAMENT TO PROHIBITION. 3. International Humanitarian Law perspective. 4. International Human Rights Law perspective. 5. Conclusions.

\section{INTRODUCTION}

The prohibition of nuclear weapons is definitely one of the most politically difficult problems that has been tackled over the decades from the Cold War until today. ${ }^{3}$ Fairly recently, in 2016, the International Court of Justice had an opportunity to issue an authoritative opinion regarding the obligations of States concerning negotiations relating to the cessation of the nuclear arms race and to nuclear disarmament (three cases filed

\footnotetext{
${ }^{1}$ A shorter version of the paper had been presented at the 2019 AHRI (Association of Human Rights Institutes) Conference in Potsdam. I would like to thank the anonymous reviewers for their comments and suggestions on how to improve the article.

2 Juris Doctor (2010), Assistant professor at the Department of Human Rights, Faculty of Law and Administration, Nicolaus Copernicus University in Toruń, Poland. ORCID: 0000-0002-7643-2681; jkapre@umk.pl.

${ }^{3}$ Regarding the politics behind the nuclear arms race see, inter alia: Keith B. Payne, Nuclear Deterrence in U.S.-Soviet Relations (2019) passim; Jain Isha, Seth Bhavesh, "India's nuclear force doctrine: Through the lens of jus ad bellum", Leiden Journal of International Law 32:1 (2019) pp. 111-130; Van Jackson, On the Brink: Trump, Kim, and The Threat of Nuclear War (2019) passim; Patricia M. Lewis, "Nuclear weapons as a wicked problem in a complex world", Nuclear Disarmament: a Critical Assessment (2019) pp. 57-71; Paul C. Avey, Tempting Fate: Why Nonnuclear States Confront Nuclear Opponents (2019) passim; Matthew Kroening, The Logic of American Nuclear Strategy: Why Strategic Superiority Matters (2018) passim.
} 
by Marshall Islands v. India ${ }^{4}$, Pakistan ${ }^{5}$ and United Kingdom), ${ }^{6}$ but instead found that it could not proceed on the merits of the cases. ${ }^{7}$ Finally, 2017 has brought the long-awaited Treaty on the Prohibition of Nuclear Weapons (TPNW). ${ }^{8}$ Transcribing the prohibition of nuclear weapons into a positive (treaty) law should - at least in theory - close the gap in the ban on weapons of mass destruction. Unfortunately, for the time being, the number of Signatory States has reached 81, and the number of States Parties is only 35. ${ }^{9}$ Moreover, a quite significant number of UN Members did not participate in the Conference and sent a clear signal that they will not support its outcomes. ${ }^{10}$ Amongst these countries were, inter alia, all the known or presumed nuclear weapon States (China, France, Russia, United Kingdom, United States, Democratic People's Republic of Korea, India, Pakistan, Israel). ${ }^{11}$ Thus, it may be anticipated that the TPNW will probably not enter into force very soon (as it requires ratification by 50 States), and when it does, it will neither be universally accepted, nor significantly influence practice of the nuclear weapon States. It is therefore justified to consider the topical problem, not from a State-oriented perspective, but from a human and environmental-centred one. The aim of the article is to explore this approach. It is based on the thesis that not would only any use of nuclear weapons be contrary to the rules of international law applicable in armed conflict, in particular the principles and rules of international humanitarian law, but it would also violate international human rights law. The article also dwells upon the general (customary) international law aspects of the topical problem.

\section{NUCLEAR WEAPONS IN INTERNATIONAL LAW - FROM DISARMAMENT TO PROHIBITION}

Notwithstanding the full awareness and knowledge about the destructive force and catastrophic humanitarian impact of nuclear weapons, steps towards the full prohibition

\footnotetext{
${ }^{4}$ Obligations concerning Negotiations relating to Cessation of the Nuclear Arms Race and to Nuclear Disarmament (Marshall Islands v. India), Jurisdiction and Admissibility, Judgment, I.C.J. Reports 2016, p. 255.

${ }^{5}$ Obligations concerning Negotiations relating to Cessation of the Nuclear Arms Race and to Nuclear Disarmament (Marshall Islands v. Pakistan), Jurisdiction and Admissibility, Judgment, I.C.J. Reports 2016, p. 552.

${ }^{6}$ Obligations concerning Negotiations relating to Cessation of the Nuclear Arms Race and to Nuclear Disarmament (Marshall Islands v. United Kingdom), Preliminary Objections, Judgment, I.C.J. Reports 2016, p. 833.

${ }^{7}$ On the ground of the lack of Court's jurisdiction under Article 36, paragraph 2 of its Statute, based on the absence of a dispute between the Parties. It should be noted however, that voting results were far from unanimous - 9:7, 9:7 and 8:8 respectively.

${ }^{8}$ Adopted on 7 July 2017 by the United Nations conference to negotiate a legally binding instrument to prohibit nuclear weapons, leading towards their total elimination, held in New York from 27 to 31 March and 15 June to 7 July 2017. Open for signature from 20 September 2017. Document A/CONF.229/2017/8, available at: https://undocs.org/A/CONF.229/2017/8 (last accessed on 20 July 2019).

9 Ratification status available at: https://treaties.un.org/Pages/ViewDetails.aspx?src=TREATY\&mtdsg no $=$ XXVI-9\&chapter $=26 \&$ clang=_en (last accessed on 6 March 2020).

${ }^{10}$ Joint Press Statement from the Permanent Representatives to the United Nations of the United States, United Kingdom, and France Following the Adoption of a Treaty Banning Nuclear Weapons, United States Mission to the United Nations (July 7, 2017), available at: https://usun.state.gov/remarks/7892 (last accessed on 3 August 2019).

${ }^{11}$ The list of participants available at: https://s3.amazonaws.com/unoda-web/wp-content/uploads/2017/08/ A-CONF.229-2017-INF-4-Rev.1.pdf (last accessed on 3 August 2019).
} 
of nuclear weapons from the beginning have reached the dead-end of the opposition of nuclear weapon States. ${ }^{12}$ Several multilateral treaties governing nuclear weapons limit their use, stockpiling, production, and testing, ${ }^{13}$ but until the adoption of the TPNW there was no conventional norm that would provide for a general prohibition of the use of nuclear weapons. Also a number of bilateral treaties and arrangements aimed to reduce or eliminate certain categories of nuclear weapons. ${ }^{14}$

The question if any use of nuclear weapons would be contrary to international law was reflected upon by the ICJ in its 1996 Advisory Opinion..$^{15}$ The Court at the time (that is 23 years ago) presented the standpoint that "in view of the present state of international law viewed as a whole, as examined above by the Court, and of the elements of fact at its disposal, the Court is led to observe that it cannot reach a definitive conclusion as to the legality or illegality of the use of nuclear weapons by a State in an extreme circumstance of self-defense, in which its very survival would be at stake". ${ }^{16}$ The ICJ relied, inter alia, on the fact that there was no general treaty prohibiting the use of nuclear weapons (obligation of nuclear disarmament), while there were treaties prohibiting biological or chemical weapons. This normative background changed in 2017, when the Treaty on the Prohibition of Nuclear Weapons (TPNW) was adopted. The full implementation of article VI NPT requires a legally binding norm to prohibit nuclear weapons - this is now possible because of the TPNW. The Treaty explicitly builds on the Non-Proliferation Treaty, as acknowledged in its preamble.

The Treaty on the Prohibition of Nuclear Weapons was adopted by a UN Conference by a vote of 122 States in favour with 1 vote against (Netherlands) ${ }^{17}$ and 1 abstention (Singapore) on 7 July 2017, ${ }^{18}$ and opened for signature by the

\footnotetext{
${ }^{12}$ In the last few years three international conferences regarding the humanitarian consequences of nuclear weapons have taken place: in Oslo (2013), in Nayarit (2014) and Vienna (2014). The majority of UN Members were represented, as well as many international organizations and NGOs. However, amongst the acknowledged and unacknowledged NWS (nuclear weapon States) only India and Pakistan were represented. Also none of the permanent members of the Security Council was present.

${ }^{13}$ Such as the Treaty of Tlatelolco (1967), the Treaty of Rarotonga (1985) and the Treaty of Bangkok (1995). See a full comparative list of treaties in: Geneva Academy of International Humanitarian Law and Human Rights, International Law and Policy Institute, Nuclear Weapons Under International Law. An Overview, October 2014, pp. 16-17, available at: https:/www.geneva-academy.ch/joomlatools-files/docman-files/ Nuclear\%20Weapons\%20Under\%20International\%20Law.pdf (last accessed on 22 August 2019).

${ }^{14}$ Such as the India-Pakistan Non-Attack Agreement (1988), the Strategic Offensive Reductions Treaty (2002) and the Joint Declaration of South and North Korea on the Denuclearization of the Korean Peninsula (1992). More information available at: https://www.nti.org/learn/treaties-and-regimes/treaties/ (last accessed on 22 February 2020).

${ }^{15}$ Legality of the Threat or Use of Nuclear Weapons, Advisory Opinion, I.C.J. Reports 1996, p. 226. For an academic discussion triggered by the Opinion see, inter alia, Laurence Boisson de Chazournes and Phillippe Sands (eds.) International Law, the International Court of Justice and Nuclear Weapons (1999), passim.

${ }^{16}$ Ibid., para 97.

${ }^{17}$ The Netherlands indicated that the TPNW is incompatible with the NATO obligations, contains inadequate verification provisions and undermines the Non-Proliferation Treaty. See Explanation of vote of the Netherlands on text of Nuclear Ban Treaty available at https://s3.amazonaws.com/unoda-web/wp-content/ uploads/2017/07/Netherlands-EoV-Nuclear-Ban-Treaty.pdf (last accessed on 4 September 2019).

${ }^{18}$ Voting results available at: https://s3.amazonaws.com/unoda-web/wp-content/uploads/2017/07/A. Conf_.229.2017.L.3.Rev_.1.pdf (last accessed on 4 September 2019).
} 
Secretary-General of the United Nations on 20 September 2017. The Treaty includes a comprehensive set of prohibitions on States participating in any nuclear weapons activities. These include undertakings not to develop, test, produce, acquire, possess, stockpile, use, or threaten to use nuclear weapons. Surprisingly - or not - the final text of the Treaty provides for a withdrawal clause in Article 17(2). The said clause grants a States Party a right to withdraw from the Treaty if it decides that "extraordinary events related to the subject matter of the Treaty have jeopardized the supreme interests of its country". It has been maintained, although several participants (Chile, Ecuador, Ghana, Palestine and South Africa), as well as the ICRC, advocated its deletion, raising the argument of the contradiction between the vague language of the withdrawal clause and the very purpose of the treaty. ${ }^{19}$ The author also fails to see how the clause is to be reconciled with the preambular concern "about the catastrophic humanitarian consequences that would result from any use of nuclear weapons" and recognition of "the consequent need to completely eliminate such weapons, which remains the only way to guarantee that nuclear weapons are never used again under any circumstances". Human rights and humanitarian reasons cannot be compromised with the unspecified supreme interests of a country. You simply cannot have your cake and eat it. It is nonetheless a radical, not to say - utopian - viewpoint, incompatible with the reality of international relations and politics that are dependent on compromise. ${ }^{20}$ As long as weapons of mass-destruction are in the possession of even a single country, there will be no mutual trust and there always will have to be a "safety valve" in arms control treaties.

As already noted, the number of Signatory States reached 70 and the number of States Parties is only 20. Even though it may be anticipated that the TPNW has little chance to enter into force in the near future (as it requires 50 States Parties) it is worthwhile to consider the potential norm-building force of the Treaty. Acceptance (ratification/accession) of the Treaty by individual States - as the evidence of relevant State practice - could lead to the crystallization of a customary norm. ${ }^{21}$ The prohibition of nuclear weapons has already been endorsed and advocated by the vast majority of countries $^{22}$ and their practice could be assessed as general (sufficiently widespread

\footnotetext{
${ }^{19}$ Laura Considine, "Contests of legitimacy and value: the Treaty on the Prohibition of Nuclear Weapons and the logic of prohibition", 95: 5 International Affairs (2019) p.1090.

${ }^{20}$ As observed by the International Association of Lawyers Against Nuclear Arms (IALANA) the inclusion of such a clause is likely to enhance universality of participation in the treaty - see: Withdrawal Clauses in Arms Control Treaties: Some Reflections about a Future Treaty Prohibiting Nuclear Weapons, paper submitted by IALANA for the UN conference to negotiate a legally binding instrument to prohibit nuclear weapons, leading towards their total elimination, 31.03.2017, A/CONF.229/2017/NGO/WP.13, p. 4.

${ }^{21}$ Daniel Rietiker, "New Hope for Nuclear Disarmament or "Much Ado About Nothing?": Legal Assessment of the New "Treaty on the Prohibition of Nuclear Weapons" and the Joint Statement by the USA, UK, and France Following its Adoption”, 59 Harvard International Law Journal (2017) p. 25-26.

${ }^{22}$ However, even though support for a nuclear weapon free world seems almost global, voting at the General Assembly does not always support that belief. At the seventeenth session in December 2015 three resolutions addressing nuclear disarmament were adopted (resolution 70/47 "Humanitarian consequences of nuclear weapons" with a voting 144-18-22; resolution 70/48 "Humanitarian pledge for the prohibition and elimination of nuclear weapons" with a voting 139-29-17, and resolution 70/50 "Ethical imperatives for a nuclear-weapon-free world" with a voting 132-36-16.
} 
and representative $)^{23}$ and consistent. ${ }^{24}$ Most probably however, at least several States would not be willing to be bound by the treaty. ${ }^{25}$ Therefore, the question is -if (sooner or later) the treaty reaches the status of ratifications leading to a (quasi) universal treaty - might it express a customary rule that also binds States that did not ratify the instrument? Would these States be considered as persistent objectors that are not bound by a customary prohibition of nuclear weapons when (if) it comes into existence? The persistent objector rule is based on the idea that it cannot prevent a customary norm from being established, but can only avoid the application of the norm in relation to a particular State or States. ${ }^{26}$ So far, the nuclear weapons States were willing to reduce and control their nuclear stockpile. However, their official statements against the TPNW (as well as earlier opposition towards further disarmament) seem to meet the criteria for the operation of the persistent objector rule: objection, persistence, and consistency. ${ }^{27}$ The United States, United Kingdom, and France issued a statement following the adoption of the TPNW where they stated that "We do not intend to sign, ratify or ever become party to it. Therefore, there will be no change in the legal obligations on our countries with respect to nuclear weapons. For example, we would not accept any claim that this treaty reflects or in any way contributes to the development of customary international law". ${ }^{28}$ This statement clearly expressed the intent of these States to be treated as persistent objectors. ${ }^{29}$ However, if the rule to be created concerns a peremptory norm of international law (jus cogens) ${ }^{30}$ or even a broader catalogue of norms (such as erga

${ }^{23}$ ICJ, North Sea Continental Shelf, Judgment, I.C.J. Reports, 1969, p. 3, para 73. The Court suggested that "a very widespread and representative participation in the convention might suffice in itself, provided it included that of States whose interests were specially affected". Which States are to be regarded as "specially affected" by the prohibition of nuclear weapons? The answer to this question seems obvious: all the States of the globe. It would be unacceptable to put forward that that only nuclear-weapon States should be regarded as such.

${ }^{24}$ Conclusion 8 in: ILC, Draft conclusions on identification of customary international law (2018). Regarding the question of quantity and quality of practice, repetition, and duration in time: Michael Akehurst, "Custom as a Source of International Law", British Yearbook of International Law (1974-1975), reprinted in Martii Koskenniemi (ed.), Sources of International Law. The Library of Essays in International Law (2000) p. 264-268; Michael Wood, Second report on identification of customary international law, 22 May 2014, A/ CN.4/627, pp. 36-40.

${ }^{25}$ Not only nuclear weapon States, but also countries hosting nuclear weapons or endorsing nuclear weapons that did not participate in the TPNW negotiations - see https:/www.icanw.org/the-facts/nuclear-arsenals/ (last accessed 9 September 2019).

${ }^{26}$ Rietiker, supra note, p. 27.

${ }^{27}$ See further: Conclusion 15 in: ILC, Draft conclusions, supra note; Elias Olufemi, "Persistent Objector", Max Planck Encyclopedia of Public International Law, p. 1, available at: http://opil.ouplaw.com/ view/10.1093/law:epil/9780199231690/law-9780199231690-e1455?prd=EPIL (last accessed on 29 August 2019); Jonathan I. Charney, "The Persistent Objector Rule and the Development of Customary International Law", 56:1 British Yearbook of International Law (1985) pp. 1-24; James A. Green, The Persistent Objector Rule in International Law (2018) Part 2.

${ }^{28}$ Joint Press Statement from the Permanent Representatives to the United Nations of the United States, United Kingdom, and France Following the Adoption of a Treaty Banning Nuclear Weapons, United States Mission to the United Nations (July 7, 2017), available at https://usun.state.gov/remarks/7892 (last accessed on 10 September 2019).

${ }^{29}$ According to the Conclusion 15 , "The objection must be clearly expressed, made known to other States $[\ldots] "$.

${ }^{30}$ Draft Conclusion 15 (3). See also Green, supra note, Part 3. 
omnes obligations ${ }^{31}$ or particularly "fundamental" customary international law norms of non jus cogens status, ${ }^{32}$ it is applicable to all States and no State can rely on the persistent objector exception. The use of nuclear weapons would almost certainly affect fundamental human rights that cannot be derogated from in time of war or other public emergency threatening the life of the nation, ${ }^{33}$ such as the right to life, the prohibition of torture, inhuman, or degrading treatment. ${ }^{34}$ This issue will be addressed in more detail in the last section of the article.

Owing to the fact that the TPNW has not entered into force yet, the Treaty on the Non-Proliferation of Nuclear Weapons (NPT) remains the most comprehensive convention in this respect. It was opened for signature in 1968 and entered into force in 1970. A total of 191 States have joined the Treaty, including the five nuclear-weapon States. ${ }^{35}$ Notwithstanding the wide acceptance of the treaty, it has been successful only partially. Its objective was to prevent the spread of nuclear weapons and weapons technology, to promote cooperation in the peaceful uses of nuclear energy, and to further the goal of achieving nuclear disarmament and general and complete disarmament. ${ }^{36}$ The goal of the global nuclear non-proliferation has largely been achieved, but the same cannot be said regarding the nuclear disarmament. Implementation of article VI slowed down. North Korea announced its withdrawal from the NPT in 2003.

The five nuclear-weapon States (recognized by the NPT) clearly aim to keep the status-quo. In the Reports on the implementation of the Treaty submitted for the Review Conference that took place in $2015^{37}$ the following justifications can be found: as for China: "China exercises utmost restraint in the development of its nuclear weapons, which

\footnotetext{
${ }^{31}$ Draft Conclusion 15 does not mention erga omnes obligations, nevertheless the commentary to it recalls that the commentary to draft conclusion 1 already makes it clear that all of the present draft conclusions are without prejudice to questions of hierarchy among the rules of international law, including those concerning peremptory norms of general international law (jus cogens), or questions concerning the erga omnes nature of certain obligations. See: ILC, Draft conclusions on identification of customary international law, with commentaries (2018), available at: http://legal.un.org/docs/?path=../ilc/texts/instruments/english/ commentaries/1_13_2018.pdf\&lang=EF (last accessed 17 August 2019).

${ }^{32}$ Green, supra note, Part 3.

${ }^{33}$ See Article 15 of the European Convention on Human Rights.

${ }^{34}$ There is a consensus about the peremptory nature of a narrow set of human rights norms: Olivier De Schutter, International Human Rights Law. Cases, Materials, Commentary (2nd ed., 2014) p. 87; Ian D. Seiderman, Hierarchy in International Law. The Human Rights Dimension (2001) pp. 66-105; Daniel Rietiker, Humanization of Arms Control: Paving the Way for a World Free of Nuclear Weapons (2017) pp. 173-95; Robert Kolb, Peremptory International Law - A General Inventory (2015) pp. 77-80; Gerard Cohen-Jonathan, Le jus cogens et le droits de l'homme, in Melanges en l'Honneur de Jan Charpentier, La France, L'Europe, Le Monde (2008) pp. 61-72.

${ }^{35}$ Status of the treaty - http://disarmament.un.org/treaties/t/npt. UK ratified in 1968, Russia and USA ratified in 1970, France and China acceded in 1992.

${ }^{36}$ Text of the treaty available at: http://disarmament.un.org/treaties/t/npt/text (last accessed 6 September 2019).

${ }^{37}$ In accordance with Action 21 of the Final Document of the 2010 Review Conference of the Parties to the Treaty on the Non-Proliferation of Nuclear Weapons, all the nuclear-weapon States are encouraged to agree on a standard reporting form and to determine appropriate reporting intervals for the purpose of voluntarily providing standard information without prejudice to national security.
} 
is consistent with its quest for their complete prohibition and thorough destruction, its nofirst-use of nuclear weapons policy and its self-defence-oriented nuclear strategy. China's first-generation leaders, Chairman Mao Zedong and Premier Zhou Enlai, unequivocally stated that "our country may manufacture a small number of atomic bombs, but we do not plan to use them ... we have them only as defensive weapons"; ${ }^{38}$ as for the United States: "The United States would only consider the use of nuclear weapons in extreme circumstances to defend the vital interests of the United States or its allies and partners [....] Nuclear plans must be consistent with the fundamental principles of the Law of Armed Conflict, and will apply the principles of distinction and proportionality and will not intentionally target civilian populations or civilian objects"; 39 as for Russia: "The current version of the Military Doctrine of the Russian Federation approved by President Vladimir Putin on December 26, 2014, is of a clearly defensive nature. According to the Doctrine, the use of nuclear weapons is strictly limited and is admitted in solely two exceptional cases: that of an attack against Russia or its allies involving the use of WMD and that of a threat to the existence of the state itself". ${ }^{40}$ As could have been anticipated from the above mentioned statements, the 2015 Review Conference of the Parties to the NPT was unable to reach a consensus on a substantive final document.

The preparatory process for the 2020 Review Conference is currently heading to an end. The third (and the last) Session of the Preparatory Committee for the 2020 Review Conference took place in April-May 2019. The current practice and statements of nuclearweapon States do not allow for any optimism regarding the outcomes of the Conference. ${ }^{41}$ Five nuclear-weapon States (recognized by the NPT) clearly aim to keep the status-quo regarding their nuclear doctrine and arsenal. In the Reports on the implementation of the Treaty submitted for the 2020 Review Conference, we find, inter alia, that "The UK independent nuclear deterrent will remain essential to our security today, and for as long as the global security situation demands", ${ }^{42}$ that "China has always upheld its commitment not to be the first to use nuclear weapons at any time and under any circumstances, in itself a practical act of nuclear disarmament" and that "China unconditionally undertakes not to use or threaten to use nuclear weapons against non-nuclear-weapon States and nuclear-weapon-free zones". ${ }^{43}$ The USA, Russia and France did not submit their reports. In February 2019 the United States and the Russian Federation issued declarations of the suspension of compliance with the obligations under the Intermediate-Range Nuclear Forces Treaty (INF), ${ }^{44}$ and in August 2019 the USA formally withdrew from the Treaty.

\footnotetext{
${ }^{38}$ Report submitted by China (NPT/CONF.2015/32), para 13.

${ }^{39}$ Report submitted by the USA (NPT/CONF.2015/38), p. 2.

${ }^{40}$ Report submitted by Russian Federation (NPT/CONF.2015/38), para 17.

${ }^{41}$ See, inter alia, a Closing Statement by the United States, available at: http://statements.unmeetings.org/ media2/21492305/us-closing-statement for-submission-to-un.pdf (last accessed on 14 September 2019).

${ }^{42}$ National Report Pursuant to Actions 5, 20, and 21 of the Nuclear Non-Proliferation Treaty (NPT) 2010 Review Conference Final Document, NPT/CONF.2020/PC.III/7, p. 2. Available at: https://undocs.org/NPT/ CONF.2020/PC.III/7 (last accessed on 15 September 2019).

${ }^{43}$ Implementation of the Treaty on the Non-Proliferation of Nuclear Weapons in the People's Republic of China, NPT/CONF.2020/PC.III/8, p. 3, available at: https://undocs.org/NPT/CONF.2020/PC.III/8 (last accessed on 19 September 2019).

${ }^{44}$ The Treaty that bans missiles with short and medium ranges was signed by the US and the USSR in 1987.
} 
These steps represent a significant setback for the nuclear disarmament process and run counter to the implementation of the Non-Proliferation Treaty's article VI obligations. ${ }^{45}$

Russia's current standpoint regarding nuclear disarmament has been articulated as follows: "For Russia, the possession of such weapons is a necessity and the only possible response to very specific external threats. It will not be feasible to renounce nuclear weapons until these threats have been addressed. At the same time, the role of nuclear weapons could be further defined and reduced in the light of developments and changes in the strategic situation". ${ }^{46}$ Similar justifications have been presented by the United States. ${ }^{47}$ Taking the above statements into consideration it may be anticipated that the disarmament process will not get much further.

"The still strong adherence to the practice of deterrence" by a few nuclear weapon States was exactly the argument on which the ICJ relied in its 1996 Advisory Opinion. ${ }^{48}$ It was deemed an obstacle to the formation and consolidation of opinio juris and a customary rule as to the illegality of nuclear weapons, leading to "a specific and express prohibition" of their use..$^{49}$ Could such a position be maintained, taking into account that today the prohibition of nuclear weapons is expressly stated in positive law? Moreover, there has been a visible development in the disarmament process since 1996 and, as already indicated, the practice of ultimately almost all other States could be assessed as general (sufficiently widespread and representative) and consistent, and therefore capable of crystallizing a customary ban on nuclear weapons. The adoption of the TPNW is definitely another important step in this direction, and the fact that 122 States supported it in voting is clear evidence of their practice. However it would be difficult to argue that it was the final and definite step of the formation of a customary norm.

To end this part of the article it should be recalled that attempts aimed at restricting the tests of nuclear weapons had also been facing problems. The treaty Banning Nuclear Weapon Tests in the Atmosphere, in Outer Space, and Under Water (known as the Partial Test Ban Treaty) was signed in 1963 and entered into force the same year. ${ }^{50}$ Throughout the 70s of the XX century, the UN General Assembly adopted several resolutions pointing out the dangers of a nuclear arms race, and calling on States to stop testing nuclear weapons, as well as to ratify the Test Ban Treaty of 1963. As we all know, nuclear testing did not stop together with the cold war. The discussion on the international forum restarted after the test conducted by France on the Pacific in the 90s. The question of the legality of nuclear tests was raised by Australia and New Zealand before the International Court of

\footnotetext{
${ }^{45} \mathrm{https}: / /$ www.nato.int/cps/en/natohq/news_162996.htm (last accessed 28 August 2019).

${ }^{46}$ Working paper submitted by the Russian Federation, NPT/CONF.2020/PC.III/WP.6, para 7, available at https://undocs.org/NPT/CONF.2020/PC.III/WP.6 (last accessed on 14 August 2019).

${ }^{47}$ Working paper submitted by the United States of America, Operationalizing the Creating an Environment for Nuclear Disarmament (CEND) Initiative, NPT/CONF.2020/PC.III/WP.43, available at: https://undocs. org/NPT/CONF.2020/PC.III/WP.43 (last accessed on 14 August 2019).

${ }^{48}$ ICJ, supra note, para. 67, 73.

${ }^{49}$ Ibid., para. 73.

${ }^{50}$ The number of States Parties is 125 . Ratification status available at: http://disarmament.un.org/treaties/t/ test_ban (last accessed on 5 September 2019).
} 
Justice. ${ }^{51}$ Efforts of the UNGA, ${ }^{52}$ as well as of other organs and institutions, finally led to the adoption (in September 1996) of the long-awaited Comprehensive Nuclear Test Ban Treaty. ${ }^{53}$ The treaty is still not in force. ${ }^{54}$

Because of the current crisis of arms control and the unwillingness of the nuclear weapon States to bind themselves with a prohibition of nuclear weapons, it is justified to look at the problem from the IHL and IHRL perspective and explore arguments against the legality of the use (or threat of use) of these weapons.

\section{InTERnational Humanitarian LaW PERSPective}

According to one of the basic principles of the IHL the right of parties to an armed conflict to choose methods or means of warfare is not unlimited. ${ }^{55}$ The aforementioned limitations can be found both in conventional, as well as in customary norms of jus in bello (international law applicable in armed conflict). Until very recently however, there was no treaty norm prohibiting the use and threat of nuclear weapons. Nevertheless, it has well been argued that even without such explicit norm, other principles and rules of IHL are applicable to the use and threats of use of nuclear weapons, such as: the rule of distinction, the prohibition against indiscriminate attacks, the rules on proportionality and precautions in attack, the prohibition on the use of weapons of a nature to cause superfluous injury or unnecessary suffering, and the rules for the protection of the natural environment. ${ }^{56} \mathrm{TPNW}$ in its Preamble explicitly provides that any use of nuclear weapons would be contrary to the rules of international law applicable in armed conflict, in particular the principles and rules of international humanitarian law.

The rule of distinction/discrimination prohibits the use of a weapon that cannot discriminate in its effects between military and civilian targets. ${ }^{57}$ The law recognizes that

\footnotetext{
${ }^{51}$ Nuclear Tests (New Zealand v. France), Judgment, I.C.J. Reports 1974, p. 457 and Nuclear Tests (Australia v. France), Judgment, I.C.J. Reports 1974, p. 253.

${ }^{52}$ Resolution A/ RES/50/7(M) of 1995 specifically recognizes the importance of considering environmental safeguards in treaties and agreements regarding disarmament, and further highlights the detrimental environmental effects of the use of nuclear weapons.

${ }_{53}^{53}$ Text of the treaty available at http://disarmament.un.org/treaties/t/ctbt/text (last accessed on 18 August 2019).

${ }^{54}$ It has a significant number of 168 States Parties, however it requires ratification by all States listed in Annex 2 to this Treaty.

${ }^{55}$ See generally: Stefan Oeter, "Methods and Means of Combat", in D. Fleck (ed.), The Handbook of International Humanitarian Law (2008) pp. 119-236; Robert Kolb and Richard Haye, Introduction to the International Law of Armed Conflicts (2008) pp. 43-49, 125-172; Ingrid Detter, The Law of War (2nd ed., 2000) pp. 276-312.

${ }^{56}$ Regarding the four core principles see: Gary D. Solis, The Law of Armed Conflict. International Humanitarian Law in War (2010) pp. 250-285. See also Stuart Casey-Maslen, "The use of nuclear weapons under rules governing the conduct of hostilities", in G. Nystuen, S. Casey-Maslen, A. Golden Bersagel (eds.), Nuclear Weapons Under International Law (2014) pp. 91-127; Simon O'Connor, "Nuclear weapons and the unnecessary suffering rule", in idem, pp. 128-147.

${ }^{57}$ According to the Rule 71 of the Customary IHRL the use of weapons which are by nature indiscriminate is prohibited. Text available at: https://ihl-databases.icrc.org/customary-ihl/eng/docs/v1_rul_rule71 (last accessed on 7 August 2019).
} 
the use of a particular weapon against a military target may cause unintended collateral or incidental damage to civilian persons and objects and permits such damage, subject to compliance with the other applicable rules of law, including the principle of proportionality. However, the weapon must have been intended for - and capable of being controlled and directed against - a military target, and the civilian damage must have been unintended and collateral or incidental. ${ }^{58}$ The rule of distinction (together with the prohibition on the use of weapons of a nature to cause superfluous injury or unnecessary suffering) has been addressed by the ICJ in the Advisory Opinion of 1966. The Court noted that "In view of the unique characteristics of nuclear weapons, [...], the use of such weapons in fact seems scarcely reconcilable with respect for such requirements". ${ }^{59}$ These humanitarian reasons however did not allow the Court to come to the conclusion that all use or threat of use of nuclear weapons would be unlawful.

Apart from the fact that not all acknowledged and unacknowledged nuclear weapon States are parties to Protocol I to the Geneva Conventions ${ }^{60}$ (India, Israel, Pakistan and the United States are not, for instance), it has been argued that the 1977 Additional Protocol I is not, as such, applicable to the use of nuclear weapons. Some scholars however present another view. ${ }^{61}$ Since the text of the Protocol is of a general character and does not refer to any specific weapon or weapon category, it should therefore be presumed to apply to any type of weapon. This interpretation has been challenged by France and the UK in their reservations to the Protocol. The UK explicitly stated that "the rules introduced by the Protocol apply exclusively to conventional weapons without prejudice to any other rules of international law applicable to other types of weapons. In particular, the rules so introduced do not have any effect on and do not regulate or prohibit the use of nuclear weapons". ${ }^{62}$ One of the reservations upon ratification made by France may suggest that there could be some (extreme) situations that would justify the use of nuclear weapons. ${ }^{63}$ France made a similar interpretative declaration to the Rome Statute, trying to exclude the application of ,war crimes” to the use of nuclear weapons ${ }^{64}$ Russia did not make any reservation of this kind. It is highly doubtful if such

\footnotetext{
${ }^{58}$ Yoram Dinstein, The Conduct of Hostilities under the Law of International Armed Conflicts (2004) pp. 116-124.

${ }^{59}$ Nuclear Weapons Advisory Opinion, supra note, para. 95.

${ }^{60}$ Protocol Additional to the Geneva Conventions of 12 August 1949 relating to the Protection of Victims of International Armed Conflicts (Protocol I), 8 June 1977.

${ }^{61}$ Eric V. Koppe, "Use of nuclear weapons and protection of the environment during international armed conflict", in Nystuen et al., supra note, pp. 247-268.

${ }^{62} \mathrm{https}$ ://ihl-databases.icrc.org/applic/ihl/ihl.nsf/Notification.xsp?action=openDocument\&documentId= 0A9E03F0F2EE757CC1256402003FB6D2 (last accessed on 25 August 2019).

63 “'Le gouvernement de la république française déclare qu'il appliquera les dispositions du paragraphe 8 del'article 51 dans la mesure oul'interprétation de celles-cine fait pas obstacleal'emploi, conformémentau droitinternational, des moyens qu'il estimerait indispensables pour protéger sa population civile de violations graves, manifestes et délibéréesdesconventionsdegenèveetduprotocoleparl'ennemi.Availableat:https://hl-databases.icrc.org/applic/ ihl/ihl.nsf/Notification.xsp?action=openDocument\&documentId=D8041036B40EBC44C1256A34004897B2 (last accessed on 25 August 2019).

${ }^{64} \mathrm{https}$ //treaties.un.org/Pages/ShowMTDSGDetails.aspx?src=UNTSONLINE\&tabid=2\&mtdsg_no=XVIII10\&chapter=18\&lang=en\#14 (last accessed on 3 March 2020).
} 
reservations are compatible with the object and purpose of the 1977 Additional Protocol I that is aimed to protect victims of international armed conflicts, and to protect the natural environment from the consequences of such conflicts. ${ }^{65}$ Purposive approach to treaty interpretation focuses on the spirit of the law and is related to the principle of effectiveness. ${ }^{66}$ A general exclusion of nuclear weapons from the scope of the Protocol, as well as reservations that justify their use in some circumstances, are in conflict with Article 1(1) of the Protocol where „High Contracting Parties undertake to respect and to ensure respect for this Protocol in all circumstances". The question of whether the war concerned is "just" or "unjust", one of aggression or of self-defence, should not affect the application of the Protocol. ${ }^{67}$ Moreover, reciprocity invoked as an argument not to fulfil the obligations of humanitarian law is prohibited and this prohibition is absolute. ${ }^{68}$ Therefore, statements by the nuclear states that they would use nuclear weapons only in „extreme situations", or if attacked with the same weapon, cannot be reconciled with the object and purpose of the Protocol. This standpoint is reinforced by the wording of the Protocol's Preamble.

Apart from the harm to the civilian population and objects, a nuclear attack would certainly be disastrous to the natural environment. The study conducted by the International Committee of the Red Cross indicated that there is a customary norm that methods of warfare causing 'widespread, long-term and severe' damage to the natural environment is prohibited. ${ }^{69}$ The threshold criteria for violation of Article I of the ENMOD Convention are either 'widespread, long-lasting or severe'.$^{70}$ The same prohibitions are listed in Articles 35(3) and 55 of the Additional Protocol I. ${ }^{71}$ These three criteria were also reflected in the Rome Statute of the International Criminal Court. ${ }^{72}$

It may reasonably be expected and assumed that the use of nuclear weapons will cause widespread, long-term, and severe damage to the natural environment and -in consequence - will "prejudice the health or survival of the population". It seems to be

\footnotetext{
${ }^{65}$ Koppe, supra note, p. 256.

${ }^{66}$ Richard Gardiner, Treaty Interpretation, 2nd edn (2015) pp. 211-222.

${ }^{67}$ See a Commentary of 1987 to the Protocol I, para 48. Available at: https://ihl-databases.icrc.org/applic/ihl/ ihl.nsf/Comment.xsp?action=openDocument\&documentId=7125D4CBD57A70DDC12563CD0042F793 (last accessed on 3 March 2020).

${ }^{68}$ Ibid, paras 49-51.

${ }^{69}$ Jean-Marie Henckaerts, "Study on Customary International Humanitarian Law: A Contribution to the Understanding and Respect for the Rule of Law in Armed Conflict" 87 (857) International Review of the Red Cross (2005) p. 202.

${ }^{70}$ Convention on the prohibition of military or any other hostile use of environmental modification techniques, New York, 10 December 1976, United Nations, Treaty Series, vol. 1108, p. 151.

${ }^{71}$ Protection of the natural environment is regulated in Article 55(1): "Care shall be taken in warfare to protect the natural environment against widespread, long-term and severe damage. This protection includes a prohibition of the use of methods or means of warfare which are intended or may be expected to cause such damage to the natural environment and thereby to prejudice the health or survival of the population". ${ }^{72}$ United Nations, Treaty Series, vol. 2187, p. 3. Intentionally launching an attack in the knowledge that such attack will cause [...] widespread, long-term and severe damage to the natural environment which would be clearly excessive in relation to the concrete and direct overall military advantage anticipated is listed in Article 8(b)(iv) as a war crime.
} 
beyond dispute that the damage caused by nuclear weapons exceeds the threshold set up by the Protocol and their use cannot be justified by military necessity. Such a standpoint has, however, not been presented by the ICJ in the 1996 Advisory Opinion. The Court had - in a rather general manner- observed that "States must take environmental considerations into account when assessing what is necessary and proportionate in the pursuit of legitimate military objectives" and that "respect for the environment is one of the elements that go to assessing whether an action is in conformity with the principles of necessity and proportionality". ${ }^{73}$ The ICJ thus found that while the existing international law relating to the protection and safeguarding of the environment does not specifically prohibit the use of nuclear weapons, it indicates important environmental factors that are properly to be taken into account in the context of the implementation of the principles and rules of the law applicable in the armed conflict. ${ }^{74}$ It further acknowledged the existence of the "general obligation of States to ensure that activities within their jurisdiction or control respect the environment of other States or of areas beyond national control" that has become "a part of the corpus of international law relating to the environment". ${ }^{75}$

The duty to protect the natural environment against widespread, long-term and severe damage has been acknowledged in the Draft principles on the protection of the environment in relation to armed conflict provisionally adopted by the ILC Drafting Committee on first reading. ${ }^{76}$ Additionally, the applicability of the principles and rules on distinction and precautions in attack, to the natural environment, ${ }^{77}$ in fact preclude the use of nuclear weapons.

\section{International Human Rights LaW Perspective}

Although the use of nuclear weapons is most often discussed in the light of international humanitarian law, international human rights law is directly relevant as well. Moreover, the human rights regime adds new arguments against the legality of nuclear weapons, strengthens protection afforded to civilians and combatants, and offers a number of implementation mechanisms. ${ }^{78}$ In other words, even if it were possible to find situations of a limited use of nuclear weapons not in violation of the IHL, human rights standards would apply (also extraterritorially and during armed conflict, albeit with some limitations) ${ }^{79}$ and would provide arguments for the illegality of such weapons.

\footnotetext{
${ }^{73}$ Nuclear Weapons Advisory Opinion, supra note, para. 30.

${ }^{74}$ Ibid., para. 33.

${ }^{75}$ Ibid., para. 29.

${ }^{76}$ Draft principle 13 [II-1, 9], ILC, Draft principles on the protection of the environment in relation to armed conflict, 06.06.2019, A/CN.4/L.937, available at: http://legal.un.org/docs/?symbol=A/CN.4/L.937 (last accessed 17 July 2019).

${ }^{77}$ Ibid., Draft principle 14 [II-2, 10].

${ }^{78}$ Regarding the interrelation between the IHL and IHRL see further Stuart Casey-Maslen, "The use of nuclear weapons and human rights" 97(899) International Review of the Red Cross (2015) pp. 663-680. The author praises the IHRL concluding that "The degree of care with regard to human life that human rights law demands in police or military operations for law enforcement significantly exceeds that which is required by the prevailing rules of IHL governing the conduct of hostilities" (p. 680).

${ }^{79}$ A question of the application of the human rights treaties in the situation of armed conflict, as well as the issues of jurisdiction will not be developed here. For this purpose see, inter alia: Louise Doswald-Beck,
} 
Because of the indiscriminate character of nuclear weapons, their use would almost certainly entail an arbitrary (not limited to intentional) deprivation of life of civilians. ${ }^{80}$ The prohibition of arbitrary deprivation of life is one of the fundamental human rights and it is non-derogable under the IHRL. ${ }^{81}$ Even though the peremptory status of the aforementioned prohibition remains a subject of scholarly discussions ${ }^{82}$ this fact does not necessarily prejudge a question if the persistent objector rule is applicable. As pointed out elsewhere in the article, a broader catalogue of norms may be considered to determine the limits of the persistent objector rule.

The threat to the right to life stemming from nuclear weapons is however not limited to the time of an armed conflict. As rightly observed by the Human Rights Committee (HRC): "This threat is compounded by the danger that the actual use of such weapons may be brought about, not only in the event of war, but even through human or mechanical error or failure". ${ }^{83}$ The HRC even suggested that the production, testing, possession, deployment, and use of nuclear weapons should be prohibited and recognized as crimes against humanity. ${ }^{84}$ In October 2018, the Human Rights Committee adopted a new General comment No. 36 (2018) on article 6 of the International Covenant on Civil and Political Rights (ICCPR), on the right to life, which reaffirms that the threat or use of nuclear weapons is incompatible with the right to life and may amount to a crime under international law. ${ }^{85}$ It is worth acknowledging that the Comment also addresses the obligation to pursue in good faith negotiations in order to achieve the aim of nuclear disarmament that was raised before the ICJ by the Marshall Islands and has remained undetermined. The new General Comment thus gives the States Parties to the Covenant clear-cut and comprehensive guidelines regarding their obligations and the implementation of the ICCPR. Its practical impact though remains uncertain, as not all of the nuclear

\footnotetext{
"Human rights and nuclear weapons", in Nystuen et al., supra note; Vera Gowlland-Debbas and Gloria Gaggioli, "The relationship between international human rights and humanitarian law: and overview", in Robert Kolb and Gloria Gaggioli (eds.), Research Handbook on Human Rights and Humanitarian Law (2013), pp. 77-103; Robert K. Goldman, "Extraterritorial application of the human rights to life and personal liberty, including habeas corpus, during situations of armed conflict", in idem, pp. 104-124.

${ }^{80}$ As clearly pointed out in the UN Human Rights Committee, CCPR General Comment No. 14: Article 6 (Right to Life) Nuclear Weapons and the Right to Life, 9 November 1984, available at: https://www. refworld.org/docid/453883f911.html (last accessed on 1 August 2019): "It is evident that the designing, testing, manufacture, possession and deployment of nuclear weapons are among the greatest threats to the right to life which confront mankind today" (para. 4).

${ }^{81}$ Antonio Cassese, "A Plea for a Global Community Grounded in a Core of Human Rights", in A. Cassese (ed.), Realizing Utopia. The Future of International Law (2012) p. 139.

${ }^{82}$ Prohibition of arbitrary deprivation of life has been listed as jus cogens by the HRC - see: UN Human Rights Committee, CCPR General Comment No. 24: Issues Relating to Reservations Made upon Ratification or Accession to the Covenant or the Optional Protocols thereto, or in Relation to Declarations under Article 41 of the Covenant, 4 November 1994, CCPR/C/21/Rev.1/Add.6, para. 10. See also Dissenting opinion of Judge Antônio Augusto Cançado Trindade (para. 180 of the Opinion) to Obligations concerning Negotiations relating to Cessation of the Nuclear Arms Race and to Nuclear Disarmament (Marshall Islands v. India), Jurisdiction and Admissibility, Judgment, I.C.J. Reports 2016, p. 255.

${ }^{83}$ HRC, GC No. 14, supra note, para. 4.

${ }^{84}$ Ibid., para. 6.

${ }^{85}$ See para. 66. Text of the General Comment available at: https://tbinternet.ohchr.org/Treaties/CCPR/ Shared\%20Documents/1_Global/CCPR_C_GC_36_8785_E.pdf (last accessed on 2 September 2019).
} 
armed States and their allies under extended nuclear deterrence doctrines are Parties to the Covenant. Moreover, even some States Parties presented negative comments towards the document and argued, inter alia, that the issue of the regulation of weapons (including WMD), fell beyond the competence of the Human Rights Committee. ${ }^{86}$ The UK stated that it disagreed with the view that the threat or use of nuclear weapons are incompatible with respect for the right to life and may amount to a crime under international law. At the same time the UK acknowledged that "the indiscriminate use of nuclear weapons is incompatible with Article 6 of the Covenant". ${ }^{87}$ It is nevertheless difficult to imagine indiscriminate use of nuclear weapons as indicated earlier in this conference paper. France, on the other hand, adopted a different standpoint, and argued that the application of the right to life during armed conflict is governed by the IHL that does not categorically prohibit the threat or use of nuclear weapons. ${ }^{88}$ While it is true that IHL does not explicitly prohibit the use of nuclear weapons, it has been argued above that it would be incompatible with its fundamental rules and principles. Moreover, the norms which best protect are the ones which apply, be they of IHL or of the ILHR.

Even if the use of a nuclear weapon did not result in an immediate loss of civilian life, it may be argued that long-term consequences from radiation etc. would be in violation of the prohibition of torture, or inhuman or degrading treatment. Taking into account that this norm is commonly regarded as jus cogens ${ }^{89}$ absolute $^{90}$ and non-derogable, the obligations of States to respect it are particularly strict. ${ }^{91}$ The use of nuclear weapons is inhuman

\footnotetext{
${ }^{86}$ Observations of the United States of America On the Human Rights Committee's Draft General Comment No. 36 On Article 6 - Right to Life, October 6, 2017, available at: https://www.state.gov/wp-content/ uploads/2019/05/U.S.-observations-on-Draft-General-Comment-No.-36-on-Article-6-Right-to-Life-.pdf (last accessed on 13 August 2019).

${ }^{87}$ Human Rights Committee Draft General Comment No. 36 on article 6 of the International Covenant on Civil and Political Rights, on the right to life. Comments of the Government of the United Kingdom of Great Britain and Northern Ireland, available at: https://www.ohchr.org/Documents/HRBodies/CCPR/ GCArticle6/UnitedKingdom.pdf (last accessed on 12 August 2019).

${ }^{88}$ Commentaires du Gouvernement français à propos du projet d'Observation générale $\mathrm{n}^{\circ} 36$ sur l'article 6 du Pacte international relatif aux droits civils et politiques, concernant le droit à la vie, available at: https:// www.ohchr.org (last accessed on 12 August 2019).

${ }^{89}$ Questions relating to the Obligation to Prosecute or Extradite (Belgium v. Senegal), I.C.J. Reports 2012, p. 422, para. 99; HRC, GC No. 24, supra note; HRC, General Comment No. 29: Derogations during a State of Emergency, UN Doc. HRI/Gen/1/Rev.7 (2004), p. 184; Al-Adsani v. the United Kingdom, ECHR Judgment 21.11.2001 [GC], appl. no. 35763/97; Erica De Wet, "The Prohibition of Torture as an International Norm of Jus Cogens and its Implications for National And Customary Law", 15(1) European Journal of International Law (2004) pp. 97-121.

${ }^{90}$ Regarding its absolute character see an interesting discussion: Steven Greer, "Should Police Threats to Torture Suspects Always be Severely Punished? Reflections on the Gafgen Case", 11 Human Rights Law Review (2011) pp.67-89; Stijn Smet, "Conflicts between Absolute Rights: A Reply to Steven Greer", 13 Human Rights Law Review (2013) pp. 469-498; Steven Greer, "Is the Prohibition against Torture and Cruel, Inhuman and Degrading Treatment Really ,Absolute' in International Human Rights Law?", 15 Human Rights Law Review (2015) pp. 101-137; Natasa Mavronicola, "Is the Prohibition Against Torture and Cruel, Inhuman and Degrading Treatment Absolute in International Human Rights Law? A Reply to Steven Greer", 17 Human Rights Law Review (2017) pp. 479-498.

${ }^{91}$ HRC, General Comment No. 23, UN Doc. CCPR/C/21/Rev.1/Add.6, para. 10. See also HRC, General Comment No. 29, UN Doc. CCPR/C/21/Rev.1/Add.11, para. 11.
} 
because - as a weapon of mass destruction - it is intrinsically indiscriminate and would cause severe and durable damage to the environment in which we live. Interdependence between the condition of the natural environment and the well-being of the human person (defined as a state when an individual is able to enjoy its human rights) ${ }^{92}$ has been widely acknowledged by the UN, ${ }^{93}$ international courts, ${ }^{94}$ and in legal scholarship. ${ }^{95}$

Apart from the strictly individual perspective (that is the one concentrated on the rights and freedoms of a direct victim), IHRL makes it possible to adopt a wider approach and take into account the concept of a potential victim ${ }^{96}$ and of collective rights (including the rights of future generations). The former concept would be problematic and not very helpful in practice, as "potentiality" has been interpreted rather restrictively. ${ }^{97}$ More potential seems to lie in linking the harm to the natural environment with human wellbeing and the health of current and future generations. ${ }^{98}$ Nuclear weapon consequences are potentially dangerous to all humankind, and thus a matter of concern of all States and of the international community as a whole. ${ }^{99}$ The global and systemic relationship between the consequences of the use of nuclear weapons for health, the environment infrastructure, food security, climate, development, social cohesion, displacement, and the global economy was acknowledged by the UNGA ${ }^{100}$ and expressed in the TPNW Preamble.

Environmental issues were invoked by the Marshall Islands which filed complaints against India, Pakistan, and the UK to the ICJ, regarding an obligation to pursue in good faith and to conclude negotiations leading to nuclear disarmament. Complaints were based on the provisions of the NPT (especially its Article VI), as well as on the customary

92 As observed by Judge Christopher Weeramantry in his Separate Opinion to Gabčikovo-Nagymaros Project (Hungary/Slovakia), Judgment, I.C.J. Reports 1997, p. 7. See para. 91 of the Opinion: "protection of the environment in international law is a sine qua non for numerous human rights such as the right to health and the right to life itself".

${ }^{93}$ See UN initiatives in this respect presented in: Bertrand G. Ramcharan, United Nations Protection of Humanity and Its Habitat. A New International Law of Security and Protection, (2016) pp. 154-162.

94 Evadne Grant, "International courts and environmental human rights: re-imagining adjudicative paradigms", in A. Grear, L. J. Kotze (eds.), Research Handbook on Human Rights and the Environment (2015), pp. 379-400.

${ }^{95}$ Dinah Shelton, "Human Rights, Environmental Rights, and the Right to the Environment", 28 Stanford Journal of International Law (1991), pp. 103-117; Alan Boyle, "The Role of International Human Rights Law in the Protection of the Environment", in A. Boyle, M. Anderson (eds.), Human Rights Approaches to Environmental Protection (1998) pp. 49-57.

${ }^{96}$ See Cançado Trindade, supra note, para. 222.

${ }^{97}$ COE/ECHR, Directorate of the Jurisconsult, Practical Guide on Admissibility Criteria (2019) p. 13, available at: https://www.echr.coe.int/Documents/Admissibility_guide_ENG.pdf (last accessed 23 August 2019).

${ }^{98}$ TPNW, Preamble. See also Legality of the Threat or Use of Nuclear Weapons, Advisory Opinion, I.C.J. Reports 1996, p. 226, para. 29, where the Court recognised "that the environment is not an abstraction but represents the living space, the quality of life and the very health of human beings, including generations unborn".

${ }^{99}$ See Cançado Trindade, supra note, paras 216-220.

100 Resolution 70/48 Humanitarian pledge for the prohibition and elimination of nuclear weapons, 11.12.2015. 
international law. ${ }^{101}$ In the complaints, the very serious consequences for human health and the natural environment caused by nuclear tests were raised. ${ }^{102}$ A question that emerges with regard to the natural environment, human rights relationship, is whether individuals could file complaints to the human rights protection organs (and possibly be awarded a just satisfaction) based on the harm to the environment caused by nuclear weapons. ${ }^{103}$ Prima facie, it seems that such complaints could be regarded as admissible ratione materiae and ratione personae. So far only one complaint has dealt with nuclear tests (in this particular case the tests were conducted in the South Pacific). ${ }^{104}$ HRC regarded the complaint inadmissible ratione personae because the applicants did not manage to prove their victim status in connection with the environmental damage. However, it cannot be excluded that if in the future, in similar cases, the applicants were able to present convincing scientific arguments and prove their status as victims of a specific environmental harm, human rights organs would look into the merits of the case and declare a violation. Such application would nevertheless be very complex and other problems could arise, especially the admissibility ratione loci, the criterion of effective control and the issue of extraterritorial application of human rights treaties (if the case were to deal with the responsibility for territories not within the jurisdiction of the Respondent State).

\section{Conclusions}

The practice of nuclear weapons States towards the testing of nuclear weapons and their use has not changed much in the decades since the Cold War. It may be anticipated that nuclear disarmament will not be continued if the "will" of States prevails over humanitarian and environmental considerations. The long awaited adoption of the Treaty on the Prohibition of Nuclear Weapons did reaffirm the fundamental importance of the humanitarian perspective with regard to nuclear weapons, however the Treaty will most probably not become binding for all UN Members (especially not for the nuclear weapon States). Even though its adoption should also be perceived as a significant step towards the crystallization of a customary obligation of nuclear disarmament, the problem of persistent objectors remains. Hence, prospects for the universal abolition of nuclear weapons are

101 Obligations concerning negotiations relating to cessation of the nuclear arms race and to nuclear disarmament, Marshall Islands v. India, Preliminary Objections, I.C.J. GL No 158, 05.10.2016.

102 "The Marshall Islands has a unique and devastating history with nuclear weapons. While it was designated as a Trust Territory by the United Nations, no fewer than 67 atomic and thermonuclear weapons were deliberately exploded as 'tests' in the Marshall Islands, by the United States. [...] Several islands in my country were vaporized and others are estimated to remain uninhabitable for thousands of years. Many, many Marshallese died, suffered birth defects never before seen and battled cancers resulting from the contamination. Tragically the Marshall Islands thus bears eyewitness to the horrific and indiscriminate lethal capacity of these weapons, and the intergenerational and continuing effects that they perpetuate even 60 years later. One 'test' in particular, called the 'Bravo' test [in March 1954], was one thousand times stronger than the bombs dropped on Hiroshima and Nagasaki” - see ICJ, doc. CR 2016/1, of 07.03.2016, p. 16, paras. 4-5.

${ }^{103}$ See further discussion in Stuart Casey-Maslen, "The Right to a Remedy and Reparation of the Use of Nuclear Weapons", in Nystuen et al., supra note, pp. 461-480.

104 Vaihere Bordes and Mr. John Temeharo v. France, Communication No. 645/1995, inadmissibility decision of 22 July 1996, available at https:/www.ohchr.org/Documents/Publications/SDecisionsVol6en. pdf. (last accessed 4 August 2019). 
rather weak. It is also unrealistic to rely on the "morality" of States and their resignation from the policy of deterrence which aims to protect national interests and sovereignty. ${ }^{105}$ It is therefore justified to turn to the arguments based on the IHL and IHRL to support the general prohibition of nuclear weapons. The answer to the provocative question put in the title of this contribution is naturally negative: there is no freedom from nuclear tests and nuclear weapons in the catalogue of human rights. In the article some arguments were presented in support of the view that nuclear weapons cannot be used consistently with IHR and IHRL. It is a somewhat idealistic ${ }^{106}$ conclusion, and some might say that it does not take into account the realpolitik considerations. ${ }^{107}$ While that is true to some extent, it does not mean that this perspective is to be abandoned, especially because the IHRL provides still underestimated mechanisms and arguments against the use (and threat of use) of nuclear weapons.

Received: October $22^{\text {nd }} 2019$

Accepted: February $12^{\text {th }} 2020$

\footnotetext{
${ }^{105}$ Michael J. Glennon, "Pre-empting Proliferation: International Law, Morality, and Nuclear Weapons", 24(1) The European Journal of International Law (2013) pp. 109-127.

${ }^{106}$ The interplay between idealism and realism in human rights, as very well reflected in different contexts in: Christian Tomuschat, Human Rights. Between Idealism and Realism (2003) passim.

${ }^{107}$ For a State-centred and international relations-centred analysis of the topical problem see Michael Quinlan, Thinking About Nuclear Weapons: Principles Problems, Prospects (2009) passim. Quinlan presents the policy of deterrence in a great detail and argues, inter alia, that nuclear weapons have made major armed conflict between advanced states almost impossible, and that this fact is an inestimable benefit to humanity which should not be overlooked.
} 